\title{
Genetic Variability and Genetic Advance of the Parameters of Water Exchange in Peanut Varieties (Arachis hypogaea L.) from the Bulgarian Selection
}

\author{
Stamatov S*, Andonov B, Chipilski R and Deshev M \\ Department of Plant Genetic Resources, Institute of Plant Genetic Resources, Bulgaria
}

Submission: February 19, 2018; Published: April 26, 2018

"Corresponding author: Stanislav Stamatov, Institute of Plant Genetic Resources-Sadovo, Drujba 2 str. 4122, Bulgaria, Email: stanislav44@abv.bg

\begin{abstract}
Water exchange indices and leaf morphometry accounted in the process of a fructifying of 6 Bulgarian peanuts (Arachis hypogaea L.) variety created for a period of 31 years have been reported. The study was done to establish the genetic variability and genetic advancement of these indicators related to tolerance of varieties to water deficit. Moderate and strong genetic advancement has been reported with fresh mass (FW), dry mass (DW), water content (WC), transpiration, and water content to leaf area ratio (WC / LA). These indicators allow for genetic improvement. In all others, there is a need to enhance the variability by hybridization or mutation. In the study process it was found that environmental conditions played a major role in the manifestation of the estimate signs.

Keywords: Peanuts; Water exchange; Genetic variability; Genetic Advance; Selection

Abbreviations: FW: Fresh Weight; DW: Dry Weight; WC: Water Content; RWC: Relative Water Content; CCL: Chlorophyll Content; LL: Leaf Length; LW: Leaf Width; LA: Leaf Area; SLA Specific Leaf Area; CTD: Surface Temperature Depression; $\sigma^{2} e$ : Environmental Variance; $\sigma^{2}$ p: Phenotypic Variance; $\sigma^{2}$ g: Genotypic Variance; Mse: Mean Square Error; Mst: Mean Square Treatment; PVC: Phenotypic Coefficient Of Variation; GVC: Genotypic Coefficient Of Variation; GA: Genetic Advance; GAM(\%): Genetic Advance As Percentage Of Mean; x: Grand Mean Of A Character
\end{abstract}

\section{Introduction}

Peanuts (Arachis hypogaea L.) are grown predominantly in semi-dry regions of the tropics, where rainfall is volatile and insufficient and causing unpredictable stress [1]. In such areas, the amount of precipitation is often unpredictable, making planning for production difficult. Even peanuts grown with irrigation may experience water shortages due to limited irrigation options or water quantities that are insufficient for optimal plant growth. Despite the adaptation to the environment, peanut production is endangered when plants are subject to uneven watering during the flowering and pouring of the kernel. In drought-tolerant plants, this effect is reduced by physiological and biochemical changes to avoid dehydration. These include the expansion of the root system, the reduction of the potentiality of leaf water ductility, the closure of the mouth and osmotic regulation [2-5].

Due to the fact that the peanuts in Bulgaria are grown under irrigation conditions, Bulgarian varieties have not been evaluated so far as regards the water exchange indicators and the morphometric parameters associated with them. The nature, impact and genetic advancement of these indicators responsible for the reaction of individual varieties to water stress have not been established.
The nature and magnitude of genetic variability are essential to any breeding program. The conclusions, depending on the nature and magnitude of genetic variability, are of vital importance for the planning of an effective program for the potential event of the sign in the new genotypes. Establishing adequate variants due to the phenotype, genotype, and environment allows for targeted selection and hybridization capabilities. Genetic advance explains the degree of progress in the indicator achieved in a given variety by a certain selection pressure. The high value of genetic advancement offers the most appropriate requirement choice. It also shows the presence of genes interacting in the expression of the indicator, suggesting a reliable improvement of the cultures by selecting such signs. Estimates of genetic advancement are more reliable and meaningful than individual parameter readings [6]. According to [7], the higher phenotypic variance (PCV \%) versus the genotype variant (GCV\%) indicates that significant impacts on the expression of the indicator have the growing conditions and the environment.

The purpose of the study is to establish whether there are the significant genetic advancement and the nature of water 
change indicators in Bulgarian peanut varieties created for a 40 year period.

\section{Material and Methods}

\section{Place of the experiment}

The experiment was conducted in the town of Sadovo, Bulgaria. The area of Sadovo is characterized by a transitional continental climate with its frequent and prolonged droughts. The average peanut vegetation period temperature for a 120 year period is $3165.2^{\circ} \mathrm{C}$, with a maximum of $23.7{ }^{\circ} \mathrm{C}$ average daily temperatures are in August. The amount of rainfall in the region is a variable character and is equal to $247.31 / \mathrm{m}^{2}$ for the period. Typical are the drought in the months July-August during the active vegetation of the crops.

\section{Plant material}

The experience was conducted with 6 varieties of Valencia peanuts from the Bulgarian selection, created for a period of 31 years. Sadovo 2609 is the oldest Bulgarian variety created in 1977. Kalina was created in 1987, Orphey and Kremena created in 2005, and Tcvetelina created in 2008.

\section{Plot experiment}

Plants of all varieties were planted in two rows of $2 \mathrm{~m}$ in length. The row spacing is $70 \mathrm{~cm}$ and the plant spacing in the row $6 \mathrm{~cm}$. In this way 66 plants were harvested from each variety. Plants were regularly irrigated during the June-August active growing season.

\section{Data collection}

The data were collected from randomized plants in 2016 and 2017 in a fructifying phase. Reported are indices relation water exchange and morphological indicators:

i. Fresh (FW, g), dry (DW, g) weight and leaf water content (WC, g). Determination of fresh weights, dry weights and relative water content of the plants was performed using an analytical balance. Biomass (dry weight) was determined by drying the samples at $104{ }^{\circ} \mathrm{C}$ for 4 hours or by reaching constant weight in three consecutive measurements Beadle. Relative water content (RWC, \%) and water quantity to a unit of dry matter synthesized ratio (g) rate of transpiration (mg/ $\mathrm{cm} 2 / \mathrm{min}$ ).

ii. Relative water content (RWC, \%) and water quantity to a unit of dry matter synthesized ratio (g). The relative water content (RWC, \%) is determined as a percentage by the following formula: OEC, \% $=(\mathrm{CMM}-\mathrm{CM}) /(\mathrm{TM}-\mathrm{CM}) \mathrm{x}$ 100 Turner.

iii. Rate of transpiration $\left(\mathrm{mg} / \mathrm{cm}^{2} / \mathrm{min}\right)$. Calculation of the transpiration intensity in $\mathrm{mg}$ water $/ \mathrm{cm}^{2}$ leaf area/min.

iv. Determination of the chlorophyll content in the CCI index. Determination of chlorophyll content. Relative to total chlorophyll content, reported as CCI (Chlorophyll content index) using the CCM 200+ apparatus, reads the total chlorophyll.

v. Leaf length (L, cm), sheet width $(\mathrm{W}, \mathrm{cm})$ and leaf area $\left(\mathrm{LA}, \mathrm{cm}^{2}\right)$. The leaf area LA $\left(\mathrm{cm}^{2}\right)$ is calculated by the formula: $\mathrm{S}=\mathrm{L} \times \mathrm{H} \times 0.60$, where: L-leaf length, $\mathrm{H}$-maximum leaf width, 0.60 is a specific peanut leaf factor.

vi. Specific leaf area (SLA, $\mathrm{cm}^{2} / \mathrm{g}$ ) and water quantity to unit leaf area ratio $\left(\mathrm{gH}_{2} 0 / \mathrm{cm}^{2}\right)$. The specific leaf area SLA $\left(\mathrm{cm}^{2} / \mathrm{g}^{-1}\right)$ is defined as the leaf area of a leaf biomass unit: SLA = LA/DW where: LA is the leaf area; DM is the biomass of the leaves.

vii. Observation of surface temperature depression of CTD $\left({ }^{\circ} \mathrm{C}\right)$ Indicator reading of Depression index of the leaf (Canopy temperature depression-CTD) with an infrared thermometer.

\section{Statistical methods}

The analysis of the variance was carried out using the statistical program SPSS 19.0. Evaluation of variation components, phenotypic and genotypic variance were evaluated according to the method proposed by [8] as follows:

1. Environmental variance $\left(\sigma^{2} e\right)=$ Mse

2. Phenotypic variance $\left(\sigma^{2} p\right)=\left(\sigma^{2} g+\sigma=e\right)$

3. Genotypic variance $\left(\sigma^{2} g\right)=\frac{M s e-M s t}{r}$ Where,

Mse-mean square error, Mst-mean square treatment and r-replications

4. Phenotypic coefficient of variation and genotypic coefficient of variation

Phenotypic coefficient of variation $(\mathrm{PCV})=\frac{\sqrt{\sigma^{2} p X}}{X} \times 100$

Genotypic coefficient of variation $(\mathrm{GCV})=\frac{\sqrt{\sigma^{2} g X}}{X} \times 100$ Where,

$\sigma^{2} p$-phenotypic variance, $\sigma^{2} g$-genotypic variance, $\mathrm{x}$ grand mean of a character

5. By [9], genetic advance (GA) and genetic advance as a percentage of a mean (GAM) were determined.

$$
G A=\frac{K \times \sqrt{\sigma^{2} p} \times \sigma^{2} g}{\sigma^{2} p}
$$

Where,

GA: Expected genetic advance

K: Standardized selection differential at 5\% selection intensity $(\mathrm{K}=2.063)$ 
$\sigma^{2} p$ : Phenotypic variance

$\sigma^{2} g$ : Genotypic variance

$G A M(\%)=\frac{G A}{X} \times 100$

Where,

GAM: Genetic advance as percentage of mean

GA: Expected genetic advance

$\mathrm{X}$ : Grand mean of a character

\section{Results}

Table 1 shows the results of the measurements of the water exchange indicators and the morphological features associated with them. The data shows that the oldest Bulgarian variety Sadovo 2609 transpire the largest water and at the same time it accumulates the least fresh and dry mass. The most effective transpiration have the newer varieties Kremena and Tsvetelina. These varieties transpirate the least amount of water but accumulate the largest amount of fresh and dry mass.

Table 1: Parameters of water exchange, morphometry and analytical-laboratory performance in plants of peanut varieties created in IPGR Sadovo.

\begin{tabular}{|c|c|c|c|c|c|c|c|c|c|c|c|c|c|c|}
\hline & $\begin{array}{l}\text { Year of } \\
\text { Creation }\end{array}$ & $\begin{array}{l}\text { FW } \\
\text { (g) }\end{array}$ & $\begin{array}{l}\text { DW } \\
\text { (g) }\end{array}$ & $\begin{array}{c}\text { RWC } \\
\%\end{array}$ & WC (g) & $\begin{array}{c}\text { g } \\
\text { water/g } \\
\text { DW }\end{array}$ & $\begin{array}{l}\text { transpiration } \\
\mathrm{mg} / \mathrm{cm}^{2} / \mathrm{min}\end{array}$ & $\begin{array}{c}\mathrm{L} \\
(\mathrm{cm})\end{array}$ & $\begin{array}{c}W \\
(\mathrm{~cm})\end{array}$ & $\begin{array}{c}\mathrm{LA} \\
\left(\mathrm{cm}^{2}\right)\end{array}$ & $\begin{array}{c}\mathrm{cm}^{2} / \mathrm{g} \\
\text { DW }\end{array}$ & $\underset{\mathrm{cm}^{2}}{\mathrm{~g} \mathrm{H}_{2} \mathrm{O} /}$ & $\begin{array}{l}\text { CTD } \\
{ }^{\circ} \mathrm{C}\end{array}$ & CCI \\
\hline $\begin{array}{c}\text { Sadovo } \\
2609\end{array}$ & 1977 & 0.2205 & 0.059 & 87.47 & 0.1614 & 2.76 & 0.21 & 4.8 & 2.41 & 7.05 & 121.7 & 0.0226 & -2.23 & 22.98 \\
\hline Kalina & 1987 & 0.3142 & 0.0825 & 86.89 & 0.2317 & 2.88 & 0.188 & 5.61 & 2.91 & 9.96 & 125 & 0.0231 & -2.73 & 21.58 \\
\hline Kremena & 2005 & 0.2856 & 0.0722 & 89.21 & 0.2134 & 3 & 0.156 & 5.46 & 2.61 & 8.56 & 120.7 & 0.0251 & -3.18 & 32.61 \\
\hline Orphey & 2005 & 0.2775 & 0.0708 & 89.17 & 0.2067 & 2.97 & 0.187 & 5.34 & 2.73 & 8.77 & 125.8 & 0.0235 & -4.52 & 31.34 \\
\hline $\begin{array}{c}\text { Tcveteli } \\
\text { na }\end{array}$ & 2008 & 0.2835 & 0.0746 & 89.14 & 0.2089 & 2.82 & 0.173 & 5.1 & 2.78 & 8.57 & 116.4 & 0.0242 & -4.23 & 23.35 \\
\hline
\end{tabular}

The largest leaves and leaf area, respectively, are characteristic of the older Kalina variety, but the variety has the lowest value of relative water content and water quantity per unit area ratio. Similar low water content rate shows the oldest variety Sadovo 2609. The newer varieties, Kremena, Orpheus and Tcvetelina are characterized by a higher degree of water content compared to the accumulated biomass.
The highest values of CTD were recorded for the oldest varieties Sadovo 2609 and Kalina, respectively-2.23 ${ }^{\circ} \mathrm{C}$ and -2.73 ${ }^{\circ} \mathrm{C}$, but the available water is used inefficiently and mainly for cooling.

The newer Kremena and Orphey varieties are distinguished with the highest relative chlorophyll content, which exceeds the reported result for Sadovo 2609 and Kalina up to 30.0\%.

\section{Discussion}

Table 2: Evaluation of mean, standard error (SE), phenotypic $\left(\sigma^{2} p\right)$, genotypic $\left(\sigma^{2} g\right)$ and environmental changes $\left(\sigma^{2} e\right)$, phenotypic $(\mathrm{PCV})$ and genotypic (GCV) coefficients, genetic advance as a percentage of the mean (GA\%) of water exchange parameters and associated morphological features.

\begin{tabular}{|c|c|c|c|c|c|c|c|c|}
\hline & Mean & $\sigma^{2} e$ & $\sigma^{2} g$ & $\sigma^{2} p$ & GCV (\%) & PCV (\%) & GA & GAM (\%) \\
\hline FW & $\begin{array}{c}0.287 \pm \\
0.008\end{array}$ & 0.02 & 0.004 & 0.024 & 21.214 & 53.387 & 0.05 & 17.39 \\
\hline DW & $\begin{array}{c}0.074 \pm \\
0.002\end{array}$ & 0.006 & 0.001 & 0.007 & 43.554 & 109.609 & 0.026 & 35.704 \\
\hline RWC & $\begin{array}{c}88.510 \pm \\
0.354\end{array}$ & 0.866 & 0.162 & 1.028 & 0.455 & 1.146 & 0.33 & 0.373 \\
\hline WC & $0.213 \pm 0.006$ & 0.015 & 0.003 & 0.018 & 24.68 & 62.111 & 0.043 & 20.232 \\
\hline g water/g DW & $2.919 \pm 0.051$ & 0.126 & 0.024 & 0.149 & 5.263 & 13.245 & 0.126 & 4.314 \\
\hline $\begin{array}{c}\text { Transpiration } \\
\text { mg/cm } / \text { min }\end{array}$ & $0.184 \pm 0.005$ & 0.012 & 0.002 & 0.014 & 25.529 & 64.247 & 0.039 & 20.928 \\
\hline L & $5.350 \pm 0.078$ & 0.192 & 0.036 & 0.228 & 3.544 & 8.92 & 0.155 & 2.906 \\
\hline W & $2.717 \pm 0.035$ & 0.085 & 0.016 & 0.101 & 4.64 & 11.676 & 0.103 & 3.803 \\
\hline LA & $8.821 \pm 0.222$ & 0.544 & 0.102 & 0.646 & 3.62 & 9.111 & 0.262 & 2.968 \\
\hline
\end{tabular}




\begin{tabular}{|c|c|c|c|c|c|c|c|c|}
\hline $\mathrm{cm}^{2} / \mathrm{g} \mathrm{DW}$ & $\begin{array}{c}121.792 \pm \\
1.893\end{array}$ & 4.636 & 0.869 & 5.506 & 0.766 & 1.927 & 0.764 & 0.628 \\
\hline $\mathrm{g} \mathrm{H}_{2} \mathrm{O} / \mathrm{cm}^{2}$ & $0.024 \pm 0.000$ & 0.001 & 0 & 0.001 & 43.159 & 108.615 & 0.008 & 35.38 \\
\hline $\mathrm{CTD}$ & $\begin{array}{c}-3.176 \pm \\
0.210\end{array}$ & 0.514 & 0.096 & 0.61 & -9.776 & -24.604 & 0.255 & 8.014 \\
\hline $\mathrm{CCI}$ & $\begin{array}{c}26.955 \pm \\
0.930\end{array}$ & 2.278 & 0.521 & 2.799 & 2.677 & 6.207 & 0.642 & 2.382 \\
\hline
\end{tabular}

The estimates of phenotypic $\left(\sigma^{2} p\right)$, genotypic $\left(\sigma^{2} g\right)$ and ecological $\left(\sigma^{2} e\right)$ variations, phenotypic (PCV) and genotypic (GCV) coefficients of variation, genetic advance and percentage of genetic progression versus mean are given in Table 2 . The data in the table shows that there is no genotypic variation in water content per leaf area unit $\left(\mathrm{gH}_{2} \mathrm{O} / \mathrm{cm}^{2}\right)$. This suggests that genes expressing the sign are homozygous as a result of the action of inbreeding. For all tested parameters, the phenotypic variance coefficient (PCV) is higher than the genotype (GCV). This fact suggests the great importance of environmental conditions on the water exchange index and leaf size of peanuts.

According to [10], PCV and GCV values of greater than $20 \%$ are considered high, whereas values of less than $10 \%$ are considered low and values between 10 and 20\% are mean. Based on this argument, fresh and dry leaf mass, water content, transpiration, and water-to-leaf area ratio are account for high genotypic variation coefficients (GCV) and phenotypic variation coefficients (PCV). This indicates that the selection can be effective on the basis of these signs and their phenotypic manifestation would be a good indicator of genetic potential. The low values of PCV and GCV in the other indicators show the necessity to create variability by hybridization or mutation followed by selection [11].

[9] Classify the values of the genetic advance as a percentage of the mean (GAM) in the following way; values of $0-10 \%$ are low, $10-20 \%$ are moderate and over $20 \%$ are high. High GAM values were recorded for the dry mass, water content, permeation, and leaf water ratio. A moderately high GAM value is observed at the fresh mass. This fact, apart from genetic progress, also points to the possibility of genetic improvement of these indicators in future work to improve breeding.

\section{Conclusion}

1. The present study identifies the presence of adequate genetic variability among 6 Bulgarian peanuts varieties (Arachis hypogaea L.) of the Valencia type.

2. The information gathered from this study can be used for a future program for the selection of peanuts resistant to water stress.

3. The oldest Bulgarian variety, Sadovo 2609, has been found to use inefficient water resources in the soil.

4. It has been found that genes expressing the ratio of water to leaf area units ( $\mathrm{gH} 20 / \mathrm{cm} 2$ ) are homozygous as a result of the action of inbreeding.
5. The role of environmental conditions has been established for the parameters of water exchange, chlorophyll content and leaf size in peanuts.

6. The low PCV and GCV values for most indicators show that variability is required in them.

7. The high and moderate GAM values reported in fresh and dry mass, water content, transpiration, and water-to-leaf area ratio suggest potential for genetic improvement

8. It is recommended that future studies on water change indicators in peanuts use molecular methods to further confirm the results of this study.

\section{References}

1. Wright GC, Nageswara Rao RC (1994) Peanut waterrelations.. In J Smartt (ed.) The groundnut crop. Chapman \& Hall, London, pp. 281325.

2. Furlan A, Llanes A, Luna V, Castro S (2012) Physiological and biochemical responses to drought stress and subsequent rehydration in the symbiotic association peanut-Bradyrhizobium sp. International Scholarly Research Network Agronomy, p. 8.

3. Junjittakarn J, Girdthai T, Jogloy S,Vorasoot N, Patanothai A (2014) Response of root characteristics and yield in peanut under terminal drought condition. Chil J Agric Res 74(3): 249-256.

4. Kottapalli KR, Rakwal R, Shibato J, Burow G, Tissue D, et al. (2009) Physiology and proteomics of the water-deficit stress response in three contrasting peanut genotypes. Plant, Cell Environ 32: 380-407.

5. Thangella P, Rao DM (2013) Differential accumulation of osmolytes in 4 cultivars of peanut (Arachis hypogaea L.) under drought stress. J Crop Sci Biotechn 16(2): 151-159.

6. Nyquist WE (1991) Crit Rev Plant Sci 10: 235-322.

7. Hdru Teklu D, Alamerew Kebede S, Gebremichael DE (2014) Assessment of Genetic Variability, Genetic Advance, Correlation and Path Analysis for Morphological Traits in Sesame Genotypes. Asian Journal of Agricultural Research 8(4): 181-194.

8. Burton WG, Devane EH (1953) Estimating heritability in tall fescue (Festuca arundinacea) from replicated clonal material. Agron J 45: 478-481.

9. Johnson HW, Robinson HF, Comstock RE (1955) Estimates of genetic and environmental variability in soybeans. Agron J 47: 314-318.

10. Deshmukh SN, Basu MS, Reddy PS (1986) Genetic variability, character association and path coefficient analysis of quantitative traits in Viginia bunch varieties of ground nut. Ind J Agric Sci 56: 515-518.

11. Tiwari DK, Pandey P, Tripathi S, Giri SP, Dwivedi JL (2011) Studies on genetic variability for yield components in rice (Oryza sativa L) 3: 7681. 
This work is licensed under Creative Commons Attribution 4.0 License DOI: 10.19080/JOJHA.2018.01.555563

\section{Your next submission with Juniper Publishers will reach you the below assets}

- Quality Editorial service

- Swift Peer Review

- Reprints availability

- E-prints Service

- Manuscript Podcast for convenient understanding

- Global attainment for your research

- Manuscript accessibility in different formats ( Pdf, E-pub, Full Text, Audio)

- Unceasing customer service

Track the below URL for one-step submission https://juniperpublishers.com/online-submission.php 